HStud 27 (2013)1, 95-106 DOI: 10.1556/HStud.27.2013.1.5

\title{
THE AESTHETICS OF THE PERIODICAL MAGYAR MÜHELY
}

\author{
KÁROLY KÓKAI \\ Department of Finno-Ugristics, University of Vienna \\ Vienna, Austria \\ E-mail: karoly.kokai@univie.ac.at
}

\begin{abstract}
The Hungarian Avant-Garde periodical Magyar Mühely has been published in Paris since 1962, from the mid-1960s on with the collaboration of Hungarian emigrants living in Vienna. The paper deals with the periodical (layout, cover design, typography) and with the published contributions (works of art, illustrations, photo documentation on the one side, texts on the other: literature, theoretical essays and documentary material) focusing on their materiality. The process of production as well as of the reception of Magyar Mühely seem to be describable correctly if its diverse media formats (periodical, text, picture, hybrid formats, such as, for example, picture poems) are understood in their materiality. The special variant of the avantgardistic aesthetics embodied in Magyar Mühely, that it provided a platform for experiment and innovation as well as for the "other", correspond with the fact that it was published by people on the margins for a marginalised, emigrant public. The paper discusses these aesthetic, organizational and political issues focusing on works of geometric art and visual poetry printed in the periodical.
\end{abstract}

Keywords: Magyar Mühely, neo-avant-garde, Alpár Bujdosó, János Megyik, Pál Nagy, emigration, avantgardistic aesthetics, Cold War

Magyar Mühely, a Hungarian language periodical, published in Paris since 1962, recently ${ }^{1}$ reached its $50^{\text {th }}$ anniversary. ${ }^{2}$ During this time the periodical changed significantly - not least because the political and cultural environment changed. The most radical change happened around 1990 when the Soviet-dominated Eastern European political system fell apart and when Magyar Mühely moved to Budapest. This paper focuses on one of the changes in the history of the periodical, the shift from modernism to Avant-Garde which happened in the early 1970s.

The environment of Magyar Mühely was defined in its early years after 1962 by the non-acceptance of the Stalinist rupture in the Hungarian cultural history between 1948 and 1956. These two dates mark decisive events in the cultural history of Hungary as well as in the lives of the editors of the periodical. In 1948 the Stalinist version of the socialist cultural politics was established in Hungary. The periodical Ujhold was withheld in May 1948, the artist society Europai Iskola was at 
the end of the year 1948 also withheld: the two circles where most of those mentioned below belonged. There remained only one version of the modernism, the so-called Socialist Realism, possible. On the other hand in 1956 emigrated those who founded the periodical six years later. As they lived outside Hungary they were able to discuss alternative modernist traditions openly. That was the reason for their interest in the people who were silenced in Hungary after 1948 such as the poet Sándor Weöres. That was the reason for their interest in the central figure of the Hungarian Avant-Garde, the writer, artist and organizer Lajos Kassák. How was this interest awakened, by which impulses was it motivated and formed? The interest in Kassák, to mention just one, was motivated by the activities of the gallery owner Denise René and the artist Victor Vasarely who succeeded in organizing Kassák exhibitions in Paris in 1960 and 1963 and who invited Kassák to Paris in 1961 and 1963 - thus at least partly by activities outside Hungary.

What the editors of Magyar Mühely were looking for and what they found - especially in the more progressive institutions of the migration such as in the Márton Szepsi Csombor, Kelemen Mikes and Peter Bornemisza circles, in Irodalmi Ujság and in Új Látóhatár ${ }^{3}$ - was precisely this tradition. That is why they published Milán Füst and Miklós Szentkuthy. In the end, what Weöres, Füst, Szentkuthy, Kassák stood for in 1948, can be summarized in the word 'modernity'. After 1948 Kassák produced art too. Nevertheless, what he made in the 1960s can be called productive only in a limited sense. The works were partly a specific version of the actual lyric abstract mood and mainly reproductions of his own works of the 1920s or recreations in the style of the 1920s. What was exhibited in the Gallery Denise René in 1960 and 1963 can be therefore called neither Avant-Garde nor Neo-Avant-Garde.

\begin{abstract}
Austria
Magyar Mühely was published in Paris but it represented the Hungarian emigration of the time throughout Western Europe and the US and was produced with the collaboration of Hungarian emigrants living in Vienna as well as others. The distribution of issues Nos 1 and 2 in Austria was managed by Sándor Lóránd Surányi, after issue No. 2 by the bookseller Rudolf Novák; contributions came from the theoretician Tibor Hanák (issues No. 6 and No. 10), the sculptor Sándor Lóránd Surányi (issue No. 10), the painter János Megyik (issue No. 11), Friedrich Czagan wrote a text on sculpture symposia (issue No. 19); on 21 April, 1967 a Magyar Mühely presentation took place in Vienna (issue No. 27); Alpár Bujdosó's Elbeszélés was published in issue No. 31 (1968). That Austria was a place where the periodical was distributed, from whence contributions came and where the periodical was presented through readings, was based on the fact that
\end{abstract}


Austria had been the first stop of most migrants of 1956 and had therefore a relatively large Hungarian minority.

To understand Magyar Mühely we have to see the Hungarian emigration to the West as a group of people aware of each other, we have to take into consideration the emigration wave of 1956 and to appreciate the role of the emigrant student organization UFHS. ${ }^{4}$ At the same time we have to take into account that in Hungary and not only in the West there existed a dissident culture and a public for it. And it is important to emphasize that figures of the non-Stalinist culture had a place in Hungary as well. This can be shown e.g. with the exhibitions of Kassák in Városi Könyvtár Esztergom 1957, Csók István Galéria Budapest 1957, Magyar Írók Szövetsége Budapest 1962, Fiatal Múvészek Klubja Budapest 1965, Műveszklub Kecskemét 1965, Megyei Könyvtár Kaposvár 1966, Fényes Adolf Terem Budapest 1967, etc. Thus artists whose public presentations were withheld in 1948 slowly found places on the margins of the official cultural politics.

Despite the fact that a list of similar names could be compiled regarding other Western European migrant centres, it is apparent that in the shift from the openness for and interest in the Hungarian modern of the 1940s (motivated by its general suppression in Hungary) to a more radical, experimental and productive cultural praxis, a "group" in Austria played a decisive role. In 1972 János Megyik and Alpár Bujdosó presented at a Magyar Mühely meeting a manifest on the Nothing, ${ }^{5}$ Tibor Gáyor, Dóra Maurer and János Megyik turned to the geometric abstraction, the plan was agreed to organize the meetings of the periodical alternately in France and in Austria. These meetings had the primary goal of unfolding the artistic praxis: each participant had a limited time to present something, collective works were made, the work of others were commented upon and discussions took place. What happened at those meetings was printed in the following issues of the periodical. And: What happened at those meetings is called NeoAvant-Garde in cultural history.

\section{The Neo-Avant-Garde Periodical as a Cultural Form}

The Periodical Magyar Mühely was intended to be published by a series of editorial boards six times per year. The formation of these editorial boards and its changes were determining what Magyar Mühely stood for. An editorial board with six members was responsible for the first issues, after issue No. 6 (1963) the board included Ervin Pátkai as an editor for art, after issue No. 10 (1964) the editorial board was reduced to four - among others because one of them, János Parancs, returned to Hungary -, after issue No. 14 (1966) the board was reduced to three members. After issue Nos 41-42 (1973) the board was joined by Magyar Múhely - Írók és Olvasók Szervezete (Hungarian Atelier - Society of Writers and 
Readers); after issue Nos 43-44 (1974) by Magyar Mühely Munkaközösség (Hungarian Atelier Working Group). After this issue Pál Nagy and Tibor Papp were editors until issue Nos 56-57 (1978) when they together with Alpár Bujdosó, took over the responsibility. This board was dissolved only with issue No. 75 (1990) as a new period in the history of the periodical, according to the political changes, started. From the moment the neoavantgardistic shift of the periodical was grasped, there were Hungarian migrants in Vienna who were active as editorial members: Bujdosó and Megyik as the leaders of Magyar Mühely - Írók és Olvasók Szervezete and Bujdosó becoming the third editor.

Magyar Mühely was the place as well as the means of cultural production. Numerous contributions came into being, commissioned by the editorial board or were conceived by their authors for this opportunity for publication. It was no accident that the periodical was named Múhely, that is a common working place, an atelier.

Looking at the contributions in Magyar Mühely the questions to be asked are: Which ideas and concepts are disseminated here? How are they related to the contemporary social and political regime? What is the ideological and symbolic work established here? What is their part in the recreation of their world?

The place of Magyar Mühely in the field of force of the Cold War has yet to be defined. Three examples illustrate that this definition will be not a simple task: in the first issue the editors published an (unpaid) advertisement for a periodical in Budapest - which caused sharp criticism of the emigration. The argument was that they supported the murderous regime of János Kádár who was responsible for killing the fellow combatants of the 1956 uprising who had been unable to flee abroad. The return of János Parancs, one of the determining editors of the first years, can be seen as a betrayal of the emigration too. Pál Nagy, one of the editors, was at the same time assistant to Dezső Albrecht and Eugene L. Metz in the Fellowship Bureau of Free Europe, a US financed centre of Cold War agitation. And the third: at the Magyar Mühely meetings in Marly-le-Roi and in Hadersdorf Béla Pomogáts and Miklós Béládi participated, two deputies of the official Hungarian cultural policy, together with a few others whose names are nowhere mentioned, who were all official and unofficial collaborators of the Hungarian State Police.

The aesthetic solution of the first years of the magazine was characterized by the cover design on the one hand and with Ervin Pátkai as editor for art on the other. Remarkably these two did not fit seamlessly together. Whereas the cover design follows the rules of the pop-aesthetics of the moment (and is comparable to the design of lifestyle magazines and covers of pop music records of the time), Pátkai belonged to the European abstract movement Informel. Thus Magyar Mühely also gave in this visual sense a place for a whole range of up-to-date movements (the new, so to speak). What Marie-Joseph Philippon, Erika Éliás and Tibor Papp, the three successive designers of the covers, produced, was, together 
with the art represented by Ervin Pátkai part of the fashionable and established modernism of the time.

In Magyar Mühely modernistic ideas and concepts were disseminated in the early years. The editors and most of the contributors were students involved in emigrant politics establishing the cultural space where representatives of the Hungarian and international modern could meet. So they printed James Joyce and Miklós Szentkuthy. They provided space for discussions of geometric art and for the interpretation of non-Marxist philosophy. After the neoavantgardstic turn of the magazine the decisive idea was to have a space for creativity, allowing for the reception and discussion of the contemporary avantgardistic developments. Thus Magyar Mühely was a sort of extra territory in which to work and to create, free from the repressions of real socialism.

Which does not mean that there are no traces of repression here, because the activities of Magyar Mühely were formed precisely by the consciousness of being an exception. One of the driving forces was to unfold a creative process uninterrupted by ideologically-motivated police intervention. Nevertheless, since all these activities took place, beginning in 1962, at a time when the socialist Eastern Block was becoming less and less hermetically closed, the Iron Curtain proved to be more and more permeable, modern and avantgardistic ideas circulated between the different Western and Eastern European countries. Modernistic and avantgardistic movements were formed in the socialist countries, unfolding specific local variants. A communication network came into existence and Magyar Mühely became one of the junctions in this network.

What were the social conditions where all that, the periodical and the meetings of Magyar Mühely, took place? At first it was that of the emigration. The special variant of the avantgardistic aesthetics embodied in Magyar Mühely, that it provided a platform for experiment and innovation as well as for the "other", corresponds with the fact that it was published by people on the margins for a marginalised, emigrant public. At the same time it was the social condition generated by the creative space itself. But first of all it was formed and distorted by the conditions of the Cold War.

To be the "other" was not intended by Magyar Mühely but it happened implicitly. Bujdosó was seen by his Austrian colleague Friedrich Hahn as the "other". The same was agreed by Dóra Maurer regarding the fact that she had no connections to her Austrian colleagues. ${ }^{6}$ This otherness motivated the migrants to work on their own oeuvre in intellectual isolation and made them to a high degree the embodiment of characteristic features of international trends of the time such as e.g. the existentialistic estrangement.

What does emigration mean here? It means that they were rooted neither and at the same time both in the Hungarian and in the West European (French, Austrian) cultural life. This is visible in Magyar Mühely and this is confirmed by the autobi- 
ography of Pál Nagy, ${ }^{7}$ in discussions with Alpár Bujdosó and by documents in Petófi Irodalmi Múzeum and in private archives. As a matter of fact, considering the Hungarian developments, ${ }^{8}$ considering the Hungarian-language avantgardistic periodical in Yugoslavia Új Symposion, considering what happened in comparable French and Austrian journals like Tel Quel after 1960 and in Neue Texte after 1968, what Magyar Mühely had was the migration. It gave an identity and a task and it provided, during the changing circumstances of the Cold War, the background to be able to invent and unfold Strategies to increase the grade of influence in Hungary itself.

What was, as to be discussed further below, not a detached space from the social and political reality. This is visible in any social and political analysis of what happened, the presence of Hungarian creative artists, the members of the State Police and the emigrants at the meetings, the inbound voyage of the emigrants and the outbound voyage of the Hungarian writers and artists or in the fact that it happened on "neutral territory".

Since Magyar Mühely was an institutionalized cultural form, it justified the society which made it possible. It was what the young, culturally open-minded migrants presented after the successful completion of their studies as an addition to the established emigrant panels and the same time what, according to the official cultural policy of Hungary the loyal emigration had to be: an enrichment, an alternative which accepted and supported the existing Hungarian culture.

\section{Materiality}

Looking at the periodical (layout, cover design, typography) and the published contributions (art works, illustrations, photo documentation on the one side, texts such as literature, theoretical essays and documentary material on the other) by focusing on their materiality we can find a series of characteristics.

Magyar Mühely has a traditional format. When compared to the other Hungarian emigrant periodicals it nevertheless gives a modernistic impression. It is a small format and therefore looks convenient. It is not made for a dignified reader but rather for a mobile one with rationalized space.

In 1972 Magyar Mühely celebrated its tenth anniversary. This obviously brought about the change. The periodical did not appear for months. The editors seem to have been standing before a psychological barrier. The question was how to continue the project.

The shift happened without a clear long term intention: in the beginning the editors published a progressive student periodical. They were interested in the new, what they encountered in Paris and what was in a sort of contrast with the rest of the emigration. What they looked for was on the modernistic edge of what the 
Szepsi Csombor etc. circles, Irodalmi Újság and Új Látóhatár appreciated and propagated. Magyar Mühely was thus in contrast with the rest of the emigration in the sense that it favoured one-sidedly the modernistic arts and literature. They invited everybody successful. So e.g., Ervin Pátkai who was presented at the second (1961) as well as at the third (1963) Paris Biennale and for whom Informel and Fluxus were important. That was what for instance Dóra Maurer's art characterized at that time too. Pátkai was at the same time an editor not narrow-minded and gave geometrical abstraction a place. The editors were also interested in the progressive movements in Hungary. They used the term "Avant-Garde" infrequently too. What followed was therefore there as a germ from the beginning. It only needed an impulse to make the next step, in the early 1970s.

The shift to the Neo-Avant-Garde happened as the covers started to follow idiosyncratic ideas, as the geometric abstraction received more and more place and as the possibilities of concrete poetry came into view. With these three decisions the periodical became more consistent and consequent. A differentiated identity, adequate to the social reality (the incrementally complicated situation of the migrants) was formed. A direction was found.

The (here relevant) aesthetic, organizational and political issues can be discussed, concentrating on the development of the so-called geometric art visible in the periodical. The formal reductions of this art form allow the examination of the limits of the abstraction drawn here. The comparison with the published manifestos permits the examination of the correspondence of the theoretical statements and the results of the artistic praxis. A parallel view of the published literary, artistic etc. production allows the examination of the praxis of appropriation in the artistic circle represented by Magyar Mühely.

The process of production as well as the reception of Magyar Mühely seem to be described correctly if its diverse media formats (the periodical, text, picture, hybrid formats such as, for example, picture poems) are understood in their materiality since the handling of this stood in the centre of the mentioned processes. At the shift to the Neo-Avant-Garde there was little the editors could hold on to. So came the materiality: the format, the receipt of the manuscripts and the illustrations, the discussions in the reduced editorial board and the work at the printing machines. This generated the meaning Magyar Mühely was intended to elicit.

What they found was the materiality of the language and of the text. Picture poems are conditioned by the definitive force of the visual appearances of the language as text, and as signs - and not only as phonetic signs but as visual elements. Concrete poetry is defined precisely by its work on the materiality of the language and of the text. Starting from the materiality of the language in the visual poetry everything which is connected to Magyar Mühely seems to be distinguished by the primacy of materiality: the performance, the presentation of texts at lectures and at the meetings emphasizes the materiality (determined by the visual, the 
acoustics, the time, the transience, the singularity, the experience) as well as the montage do: in the cases of guest texts, quotations, palimpsest and in the case of the montage of the issues of Magyar Mühely.

The next characteristic is estrangement. Nagy in front of his composing machine, Bujdosó at his desk or in front of the projector, worked with text pieces and fragments in a way which shows the distance, the non-arrival, the strangeness that is estrangement. That way they reach a new level of decontextualisation. The previous level was the cutting and montage of what the Avant-Garde (Kurt Schwitters) and Neo-Avant-Garde (Eugen Gomringer) did. The next step was the theoretization of the Nothing and the works by Nagy, Papp and Bujdosó.

A semmi konstrukciója by Bujdosó and Megyik was inspired by philosophy, first of all by Ludwig Wittgenstein's Tractatus Logico Philosophicus. This is obvious in its structure and its subject. The structure follows that of the Tractatus presenting similarly numbered lines of arguments. The subject here too was the tension between what can be talked about and what cannot. In opposition to Wittgenstein according to whom, in front of the unsayable we have to be silent, Bujdosó and Megyik spell out that the arts are talking about it (which is the opinion of Wittgenstein too, only he is naturally not saying so). There is nonetheless a big difference between the Tractatus Logico Philosophicus and A semmi konstrukciója. The first is a philosophical text, the second a statement by two artists and itself belongs rather to art.

\section{The Neo-Avant-Garde Cultural Practice}

Neo-Avant-Garde as a cultural practice appeared in the periodical Magyar Mühely and at the Magyar Mühely meetings. The radical modernistic aesthetics of the individual contributors served as means of intensifying the artistic production, to create a productive environment, to share a creative space. In the centre of this activity the intention was to stress the defamiliarising effects of language use. A text was taken, cut into pieces, rearranged etc., thus it was handled as material and was not written in the traditional sense. In the same way the geometric abstraction was reduced. Here the reduction went to geometry, that means elementary forms. These forms were varied, altered, set in a series. They were taken as simple elements, as signs, and were worked with. The same is true for the theoretical texts. ${ }^{9}$

Neo-Avant-Garde can be characterized by a qualitatively different way of dealing with materiality (of language, etc.). What in the case of the Avant-Garde happened because of external circumstances (they had not the technical and financial means to do it otherwise) and mostly without any theoretical reflection, was central in the case of the Neo-Avant-Garde. They reflected it thoroughly and only in these broken forms, as estranged, turned into works of art. Neo-Avant-Garde 
differentiated itself from the Avant-Garde by the fact that what in the first case was driven by the belief in the possibilities of an open future was in the second case placed on a more reflected, theoretically saturated basis, oscillating between irony and obsession, that means on a far higher level.

Labyrinth by Pál Nagy ${ }^{10}$ is composed from textual elements taken from the realm of the classics (Greek philosophy, Greek mythology) and popular science, completed with associative groups of words. This fills carpet like a double page, without a beginning or an end. Not only the content is important here but also the textual appearance. The text is set in normal rows and allows it to be read continually. The omissions between the words and the phrases, the over-the-surface distributed capitals Z, R, M, S, H, E, É, the four pictures (two riders and two servants from children books, a sign for labyrinth from a popular science work on ancient architecture and an arrow) appear to be part of a joke and is at the same time a step toward picture poems.

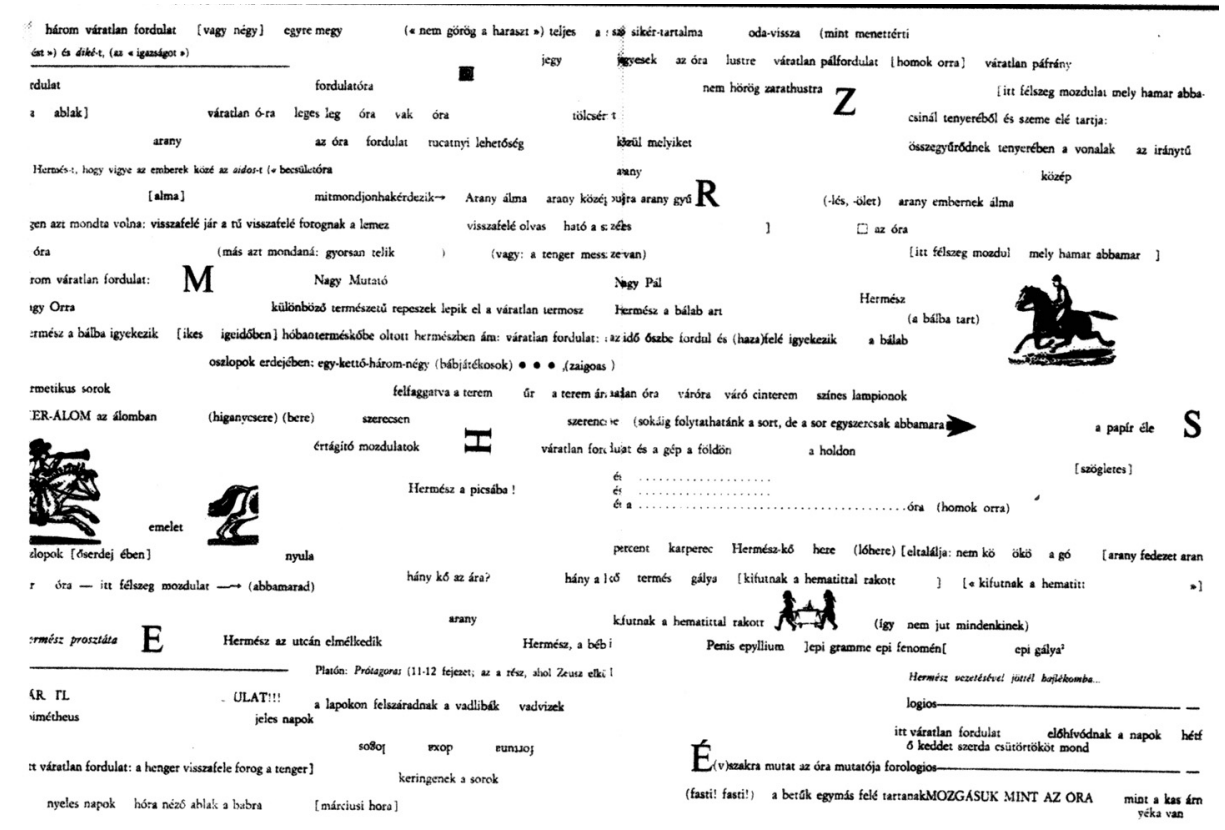

Pál Nagy, Labyrinth, 1974

In A semmi konstrukciója Bujdosó and Megyik wrote:

The arts with different methods approach the inconceivable and bring information about it. ${ }^{11}$ 
and further:

Since the inconceivable is not material, it can be handled by the material methods of art only as a complex sign. It seems that the complex sign can be handled in at least two ways.

One of these ways is the concept art (3.2). The other is what Bujdosó and Megyik want to use (3.3):

Our experimental settings are directed towards the searching for non-controversial elements and the construction of non-controversial, one poled works from these.

What this 'other way' is is not entirely clear from A semmi konstrukciója, only the above claims that this is possible. The text should therefore be seen rather as an invitation to study the work of Bujdosó and Megyik as examples. And instead of describing these works it is better to show them.

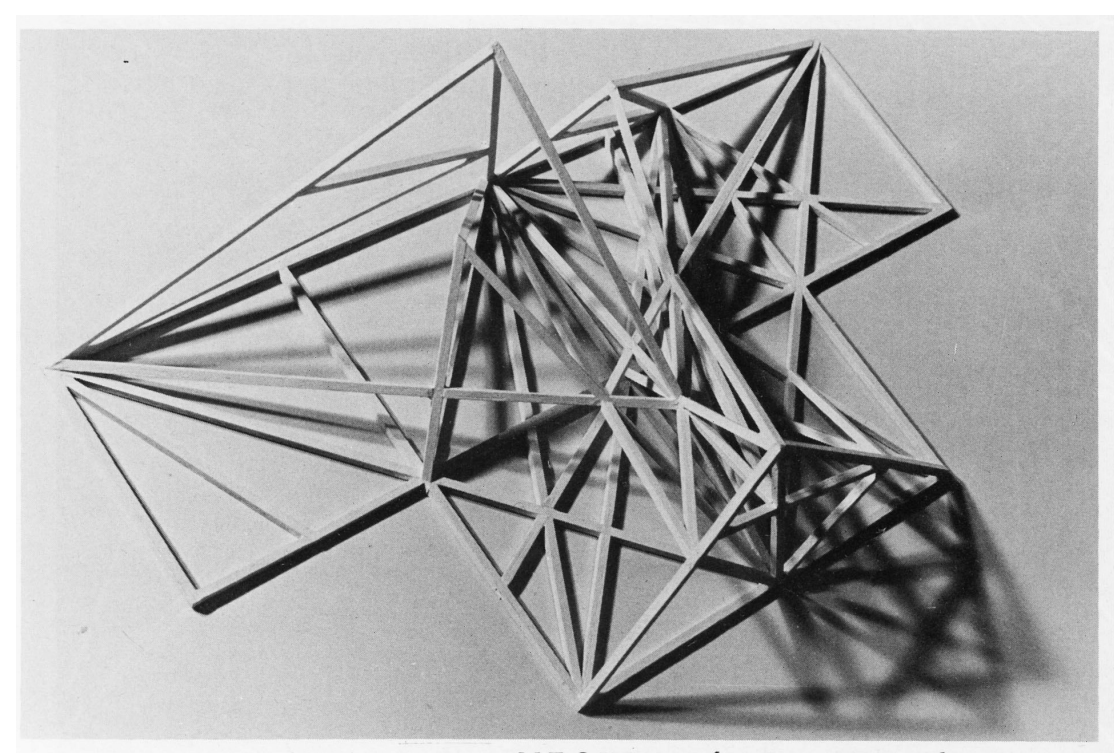

János Megyik, Construction, 1974

A brief analysis of these two texts makes it obvious that these are productive ones. They are productive in the sense that they are what they are searching for. And they are productive in the sense that they take a position. They articulate certain ideological contents, reject others and allow themselves to be innovative in ideological considerations, e.g. in their opposition of matter and idea: 
1. The arts approach with different methods the inconceivable and bring information about it.

1.1. The inconceivable is not material, the means of the conceptualization are first of all material. The colour, the form, the sound, the word are material. Everything we can experience with our senses. In this sense the communicated thought is material too, precisely because of the materiality of conceptualization needed for the communication.

1.1.1. Because we have only material tools and the inconceivable is not material, because of this qualitative difference we are using the term inconceivable. We could use as well the terms transimaginable subject or the nothing. The 'nothing' in this sense is not identical with the concept of absence.

Thus they are engaged texts, embedded in concrete ideological discussions.

Magyar Mühely helped to reproduce the existing social order by taking a contradictory place in the culture of the Cold War. This corresponded, according the order of the Cold War, to a West where the Neo-Avant-Garde was the culturally progressive and an East where the Neo-Avant-Garde was the divergent, the rebellious and the dissident. The emigration had its place in this too. It mediated not only the results of the Neo-Avant-Garde of the West but provided an extraterritorial place of production and an own version of it as well.

What happened in the periodical and at the meetings was nevertheless the constitution of not only a creative space but at the same time the expression of a critical attitude against the phenomena of representation. The material estrangement of the periodical and of the singular works created in its context correspond with this attitude. This was the exceptional situation providing the place and the structures which enabled the coming into being of the Hungarian Neo-Avant-Garde.

\section{Notes}

1 This article is based on a text presented at the $3^{\text {rd }}$ Conference of the European Network for Avantgarde and Modernism Studies on Material Meanings in Canterbury, 7-9 September 2012.

2 The anniversary was celebrated among others at the conference A Magyar Mühely évtizedei and with the exhibition Betük kockajátéka - A párizsi Magyar Mühely öt évtizede [The Dice Game of Letters - Five Decades of the Parisian Magyar Mühely] both in Petőfi Irodalmi Múzeum in Budapest in May 2012.

3 See Gyula Borbándi, A magyar emigráció életrajza 1945-1985 [A Biography of Hungarian Emigration 1945-1985] (Bern: Európai Protestáns Magyar Szabadegyetem, 1985).

4 The Union of Free Hungarian Students existed between 1957 and 1967. Among its activists were members of the circle of Magyar Mühely as well, e.g., Alpár Bujdosó and Pál Nagy. 
5 Alpár Bujdosó and János Megyik, "A semmi konstrukciója," Magyar Mühely Nos 43-44, 33-39, 1974.

6 Both reported similar experiences in two separate discussions with the author in December 2011.

7 Pál Nagy, journal in-time él(e)tem [journal in-time my life] 3 volumes (Budapest: Kortárs Kiadó 2001, 2002, 2004).

8 See e.g., Mihály Vajda et al. (eds), Hatvanas évek [Sixties] (Budapest: Képzőmúvészeti Kiadó, 1991).

9 Beside the mentioned text of Bujdosó and Megyik e.g., in Miklós Erdély Marly tézisek [The Marly theses]. Magyar Mühely, Nos 60-61, 1-3, 1980.

10 Pál Nagy's work was published in Magyar Mühely issue Nos 43-44, 8-9, 1974. The title appeared in the content table of the issue as a non-alphanumerical sign which could be interpreted as "labyrinth".

11 Translation by Károly Kókai. 